УДК 636.5/591.433

DOI: 10.31208/2618-7353-2020-9-30-38

ОСОБЕННОСТИ ПОСТЭМБРИОНАЛЬНОГО РАЗВИТИЯ ЖЕЛЕЗИСТОГО ЖЕЛУДКА ЦЫПЛЯТ КРОССА РОСС 308

\title{
FEATURES OF POSTEMBRIONAL DEVELOPMENT IRON STOMACH CHICKEN CROSS ROSS 308
}

Курмашева С.С., соискатель

Сложенкина М.И., доктор биологических наук, профессор, член-корреспондент РАН Комарова 3.Б., доктор сельскохозяйственных наук, доцент

Головин В.В., соискатель

Воронина Т.В., соискатель

Kurmasheva S.S., applicant

Slozhenkina M.I., doctor of biological sciences, professor, correspondent member of RAS Komarova Z.B., doctor of agricultural sciences, associate professor

Golovin V.V., applicant

Voronina T.V., applicant

Поволжский научно-исследовательский институт производства и переработки мясомолочной продукции», Волгоград

\author{
Volga Region Research Institute of Manufacture and Processing \\ of Meat-and-Milk Production, Volgograd
}

Работа выполнена в рамках гранта Президента РФ НШ-2542.2020.11.

Статья посвящена изучению постэмбрионального развития железистого желудка цыплят-бройлеров кросса Росс 308. Учитывая, что существует связь между живой массой и скоростью созревания птицы, ее сохранностью и деловым выходом, то становится очевидным, что изучение процессов роста и развития молодняка позволит объективно обосновать эффективность выращивания конкретного кросса птицы. Авторами в динамике (1-40 суток) изучена морфология железистого желудка цыплят на уровне микроструктуры. Результаты гистологической структуры железистого желудка цыплят позволили установить равномерное увеличение толщины мышечной пластинки, которая к 38-дневному возрасту увеличилась в 1,71 раза. Доказано, что у суточных цыплят толщина слизистой оболочки железистого отдела желудка цыплят составила 361,2 мкм и к 5 суткам увеличилась до 386,7 мкм. В течение 6 и 7 суток рост клеток замедлился, а к 10 суткам толщина слизистой оболочки железистого отдела желудка увеличилась до 399,9 мкм, к 20-суткам - до 426,73 мкм, к 25 суткам - до 433,13 мкм. С 29 суток произошел резкий скачек роста клеток слизистого эпителия. К 30 суткам толщина слизистой оболочки составила 447,21 мкм. До окончания периода выращивания цыплят наблюдали постепенное увеличение толщины слизистой оболочки, которая к 38 суткам увеличилась на 182,67 мкм и составила 615,8 мкм. Мышечная пластинка слизистой оболочки железистого отдела желудка увеличивала свои размеры постепенно. К 10 суткам данный показатель увеличился до 9,34 против 7,86 мкм в суточном возрасте. Толщина мышечной пластинки у 20-суточных цыплят-бройлеров увеличилась на 1,43 мкм, а к 30 суткам изучаемый показатель возрос еще на 1,37 мкм, у 38-суточных цыплят-бройлеров толщина мы- 
шечной пластинки изменилась незначительно и составила 12,91 мкм. Установлено, что у суточных цыплят-бройлеров толщина подслизистой основы железистого отдела желудка составила 1769,88 мкм, на 5 сутки увеличилась в 1,55 раза и составила 2743,31 мкм, на 10 сутки достигла 2837,03 мкм, на 20 сутки - 2984,64 мкм, на 30 сутки - 3705,89 мкм и на 38 сутки 4190,89 мкм. Зафиксированы периоды покоя роста клеток в развитии слизистой и подслизистой основы железистого желудка (6-7, 13-14 и 27-28 дни). Полученные результаты исследований позволяют в более ранние сроки, в возрасте 7 дней, осуществлять смену престартерного рациона кормления на стартерный, что повышает экономическую эффективность производства мяса бройлеров. Подобные исследования проводились впервые.

The article is devoted to the study of the postembryonic development of the glandular stomach of Ross 308 broiler chickens. Given that there is a connection between live weight and poultry maturation rate, its safety and business yield, it becomes obvious that studying the growth and development of young animals will objectively justify the effectiveness growing a specific cross bird. The authors in dynamics (1-40 days) studied the morphology of the glandular stomach of chickens at the microstructure level. The results of the histological structure of the glandular stomach of chickens made it possible to establish a uniform increase in the thickness of the muscle plate, which increased by 1.71 times by the age of 38 days. It was proved that in day-old chickens, the thickness of the mucous membrane of the glandular stomach of chickens was 361.2 microns and increased to 386.7 microns by 5 days. Over the course of 6 and 7 days, cell growth slowed down, and by 10 days the thickness of the mucous membrane of the glandular stomach increased to $399.9 \mu$ m, by 20 days to $426.73 \mu \mathrm{m}$, and by 25 days to $433.13 \mu \mathrm{m}$. From 29 days there was a sharp jump in the growth of mucosal epithelial cells. By 30 days, the thickness of the mucous membrane was 447.21 microns. Until the end of the period of growing chickens, a gradual increase in the thickness of the mucous membrane was observed, which by 38 days increased by $182.67 \mu \mathrm{m}$ to $615.8 \mu \mathrm{m}$. The muscular plate of the mucous membrane of the glandular stomach increased gradually. By 10 days, this indicator increased to 9.34 against 7.86 microns in daily age. The muscle plate thickness in 20-day-old broiler chickens increased by $1.43 \mu \mathrm{m}$, and by 30 days the studied parameter increased by $1.37 \mu \mathrm{m}$, in 38-day-old broiler chickens the thickness of the muscle plate slightly changed and amounted to 12.91 microns. It was established that in daily broiler chickens the thickness of the submucosa of the glandular stomach was $1769.88 \mu \mathrm{m}$, on the 5th day it increased 1.55 times and amounted to $2743.31 \mu \mathrm{m}$, on the 10th day it reached $2837.03 \mu \mathrm{m}$, on the 20th day - 2984.64 microns, on the 30th day - 3705.89 microns and on the 38th day-4190.89 microns. The periods of rest of cell growth in the development of the mucous and submucosal bases of the glandular stomach were recorded (6-7, 13-14 and 27-28 days). The research results allow earlier, at the age of 7 days, to change the starter feeding ration to the starter one, which increases the economic efficiency of broiler meat production. Similar studies were conducted for the first time.

Ключевые слова: цыплята-бройлеры, железистый желудок, гистоструктура.

Key words: broilers, glandular stomach, histostructure.

Введение. Залог успеха современного птицеводства и тем более его интенсификация всегда основываются на знаниях биологии птиц, её морфофункциональных особенностей и, в частности, органов пищеварительного аппарата, участвующих в обменных и энергетических процессах организма. Рост массы тела и синтез яйца не только приоритетны для функции организ- 
ма, но они практически всегда опережают рост костей, развитие кожных покровов и внутренних органов у птиц, в результате чего во второй половине выращивания цыплят-бройлеров наблюдается повышенный отход птиц, а высокая живая масса цыплят в конце откорма создает проблемную ситуацию с реализацией $[1,5,10,14]$. В связи с этим изучение закономерностей развития структурной организации органов пищеварения птиц и их адаптационных перестроек - одна из фундаментальных проблем современной биологической науки и сельскохозяйственной практики [2, 3, 4, 7].

Пищеварительная система, обеспечивающая непрерывность потока веществ и энергии в организме, рассматривается как одна из наиболее лабильных систем, реагирующих значительными и долговременными структурно-функциональными изменениями на воздействие эндо- и экзогенных факторов $[6,11,12,13]$.

Изучение строения пищеварительного тракта птицы определяет перспективы повышения её продуктивности. В первую очередь это относится к возрастной морфологии, которая, раскрывая морфогенетические закономерности и механизмы, позволяет выявить переломные периоды развития отдельных систем организма $[8,9]$.

Содержащиеся в отечественной и зарубежной литературе сведения по морфологии железистого желудка птиц носят фрагментарный и разрозненный характер и не позволяют получить целостное представление о росте и развитии органа в постинкубационном онтогенезе.

Эти исследования, на наш взгляд, представляют теоретический и практический интерес для биологии индивидуального развития, ветеринарной медицины, зоотехнии и морфологии.

Материалы и методы. Объектом исследований служили цыплята-бройлеры кросса Росс 308, содержащиеся в условиях ООО «Фрегат-Юг» Волгоградской области. Содержание и кормление птицы проводилось согласно нормам и требованиям к хозяйствам промышленного типа, предусмотренным для данного вида птицы. Для опыта были отобраны 200 голов суточных цыплят. Продолжительность опыта составила 40 дней, убой птицы проводили ежедневно в количестве 5 голов.

Материалом для исследования служили желудки клинически здоровых особей опытных цыплят-бройлеров. Умерщвление птицы проводили путем обескровливания (Комаров А.В., 1981). Анатомическое вскрытие тела птицы проводили согласно методике, предложенной Жаровым А.В. (2000).

При работе с птицами полностью соблюдали Международные принципы Хельсинской декларации о гуманном отношении к животным.

Органы фиксировали в 10\%-ном растворе формалина, забуференном по Лилли. Для проведения гистологического исследования использовали кусочки размером $1 \mathrm{x} 1 \mathrm{x} 0,5$ см в однотипных местах.

Изучение структурных компонентов органов пищеварительной системы цыплятбройлеров на гистологических препаратах проводилось с помощью микроскопа Carl Zeiss Axiostar Plus. Для получения достоверной информации гистометрические измерения структур органа проводились методом случайного отбора поля зрения микроскопа при помощи специальной установки «iVizo-103».

Результаты и обсуждение. Установлено, что динамическое изменение пищеварительного аппарата у кур на уровне микроструктуры соответствовало возрасту цыплят.

При этом стенка железистого желудка молодняка состояла из слизистой оболочки с подслизистой основой, мышечной и серозной оболочек. Макроскопически слизистая оболочка желудка бледно-розового цвета, гистологически состояла из поверхностного эпителия, собственной пластинки и мышечной пластинки (рисунок 1). 


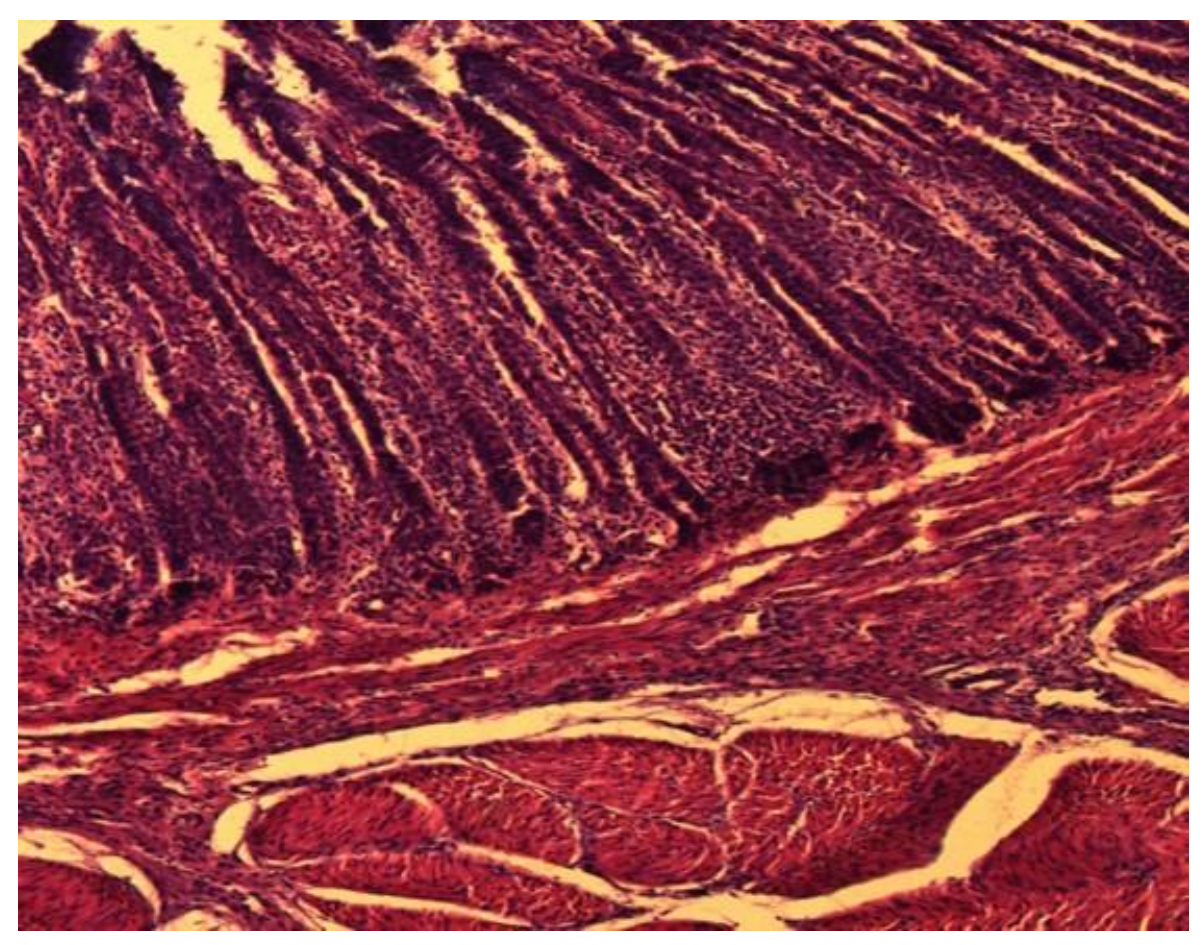

Рисунок 1 - Структурная организация железистого желудка у цыплят на 16 день постнатального онтогенеза. Окр. гематоксилин-эозин, ув.10×0,3

Figure 1 - Structural organization of the glandular stomach in chickens on day 16 of postnatal ontogenesis. Okr. hematoxylin-eosin, increase $10 \times 0.3$

Эпителиальный слой слизистой оболочки состоял из однослойного призматического эпителия. Собственная пластинка слизистой оболочки образована рыхлой соединительной тканью с большим количеством клеточных элементов, в том числе лимфоидных фолликулов.

В подслизистом слое слизистой оболочки расположены сложные альвеолы ворсинок железы, которая представлена рыхлой соединительной тканью и развита незначительно. Ворсинки состоят из нескольких крупных округлых долей глубиной до 2 мм. Каждая доля состоит из большого числа альвеол ворсинок (рисунок 2).

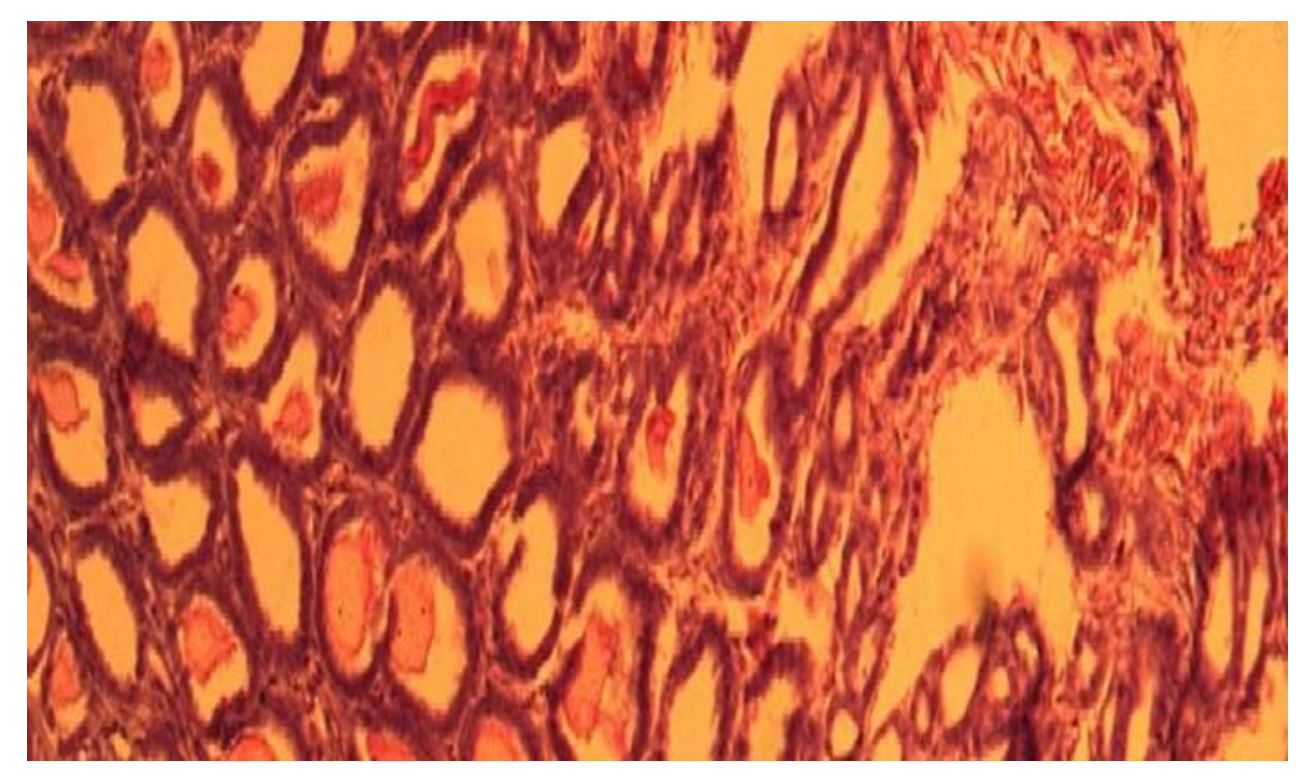

Рисунок 2 - Расширение альвеолярных полостейворсинок на 32 день развития. Окр. гематоксилин-эозин, ув. $\times 400.10 \times 0,3$

Figure 2 - Expansion of the alveolar cavity of the villi on day 32 of the development.

Okr. hematoxylin-eosin, increase $\times 400.10 \times 0.3$

Стенка ворсинок образована однослойным эпителием, клетки которого в зависимости от фазы секреции имели разную форму - от кубической до цилиндрической (рисунок 3: а, б). 


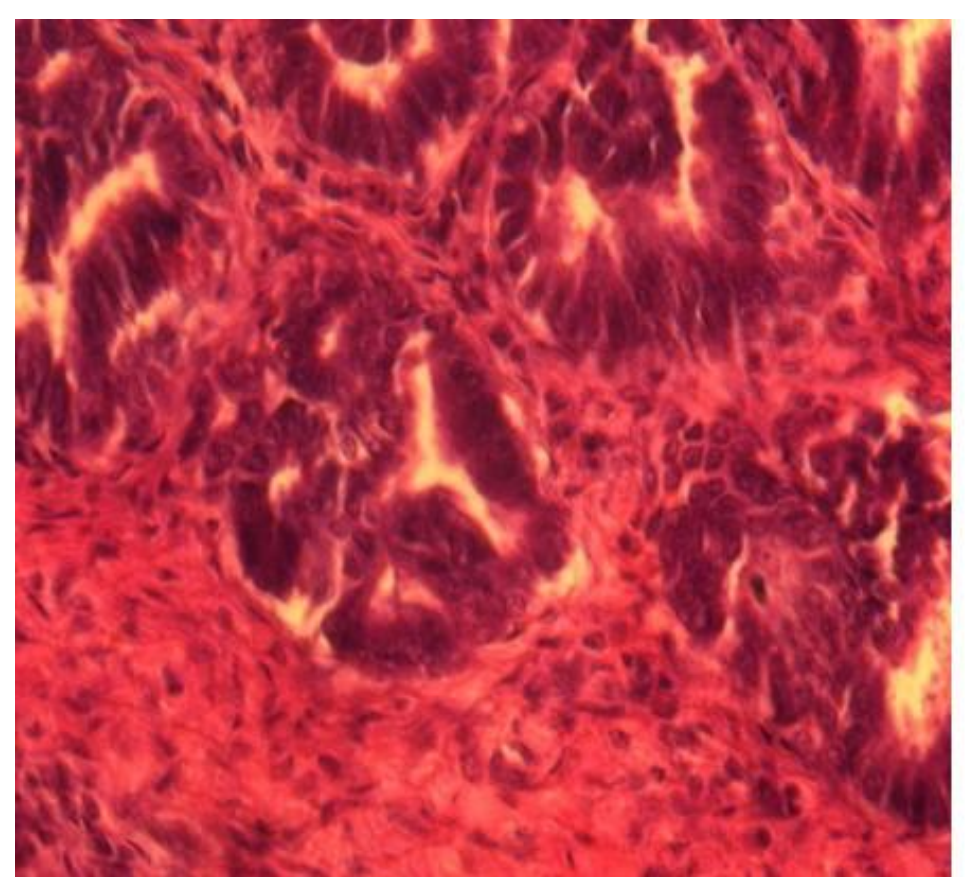

a)

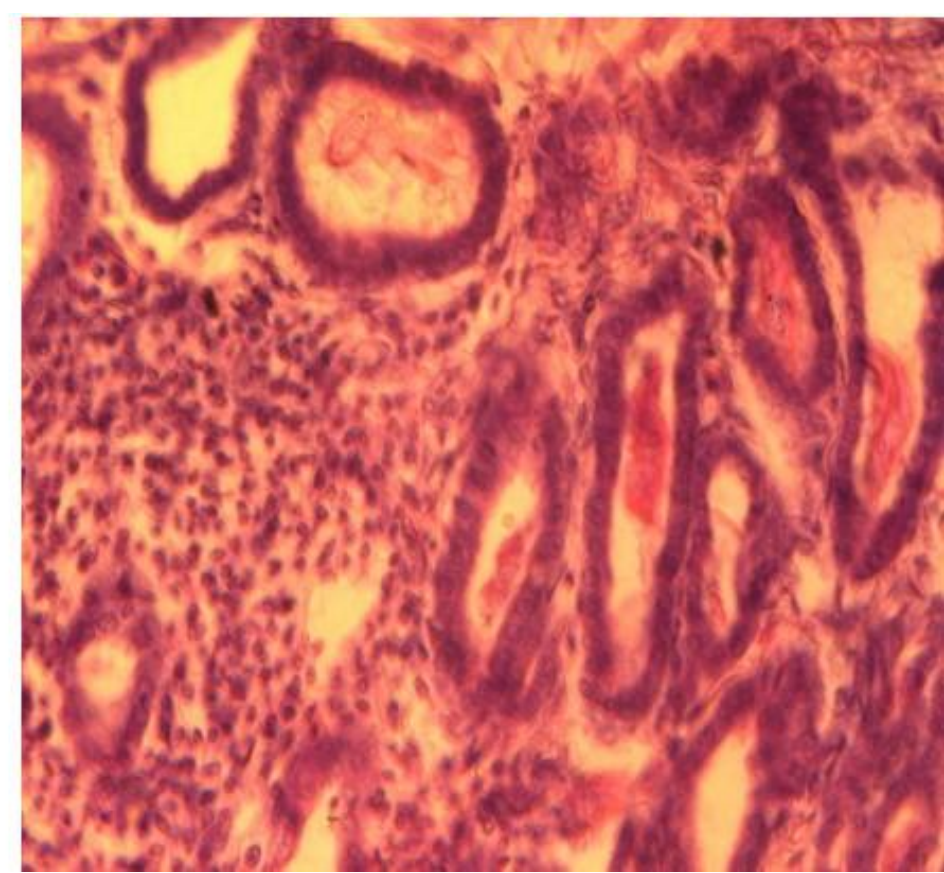

б)

Рисунок 3 - Структурная организация трубчатых желез:

a) стенка альвеолы, выстланная цилиндрическим эпителием, мощные прослойки соединительной ткани на 31 день развития, $40 \times 0,75$; б) секреторные клетки желез кубической формы на 32 день развития, $40 \times 0,75$. Окр. гематоксилин-эозин, ув. $\times 400$ Figure 3 - The structural organization of the tubular glands:

a) the wall of the alveoli lined with a cylindrical epithelium, powerful layers of connective tissue on the 31 st day of development, $40 \times 0.75 ; b$ ) secretory cells of the glands of a cubic form on day 32 of development of $40 \times 0.75$. Okr. hematoxylin-eosin, increase $\times 400$

Микроструктура апикального конца клеток характеризовалась неплотным прилеганием друг к другу и выпячиванием в просвет альвеол, особенно у клеток, заполненных секретом (рисунок 3 а). Между клетками оставались щелевидные пространства. Доли желез со всех сторон окружены соединительной тканью, содержащей коллагеновые и эластические волокна, а также пучками мышечных клеток, кроме того, были заполнены секретом, и к железам подходила большая сеть мелких кровеносных сосудов и капилляров. Мышечная пластинка слизистой оболочки образована отдельными пучками гладких миоцитов.

Мышечная оболочка железистого отдела желудка состоит из трех слоев гладких мышечных волокон: внутреннего и наружного, представленных продольными мышцами, и среднего, образованного кольцевыми, расположенными пластами. Средний слой наиболее развит.

У суточных цыплят толщина слизистой оболочки железистого отдела желудка составила $361,2 \pm 3,42$ мкм и к 5 суткам увеличилась до $386,7 \pm 5,71$ мкм, что на 25,5 мкм больше, чем у суточных цыплят. В течение 6 и 7 суток рост клеток замедлился. К 10 суткам толщина слизистой оболочки железистого отдела желудка увеличилась на 13,2 мкм и составила $399,9 \pm 4,33$ мкм. На 15 сутки толщина слизистой оболочки составила 404,0 3,22 мкм, что на 4,1 мкм больше, чем у предыдущего возраста. Толщина слизистой оболочки у 20 -дневных цыплят-бройлеров составила 426,73 $\pm 2,64$ мкм, на 25 сутки увеличилась на 6,40 мкм и составила $433,13 \pm 1,85$ мкм. В возрасте 27 и 28 дней наблюдалась пауза в росте слизистой оболочки железистого отдела желудка. Увеличение толщины слизистой оболочки за 2 суток составило 0,6 мкм. С 29 суток произошел резкий скачок роста клеток слизистого эпителия. К 30

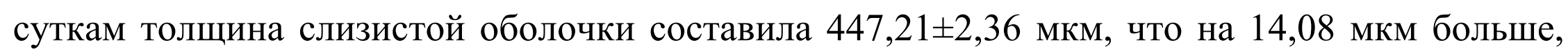
чем у 25-суточных цыплят-бройлеров. До окончания периода выращивания цыплят наблю- 
дали постепенное увеличение толщины слизистой оболочки, которая к 38 суткам увеличилась на 182,67 мкм и составила 615,8 33,88 мкм (рисунок 4).

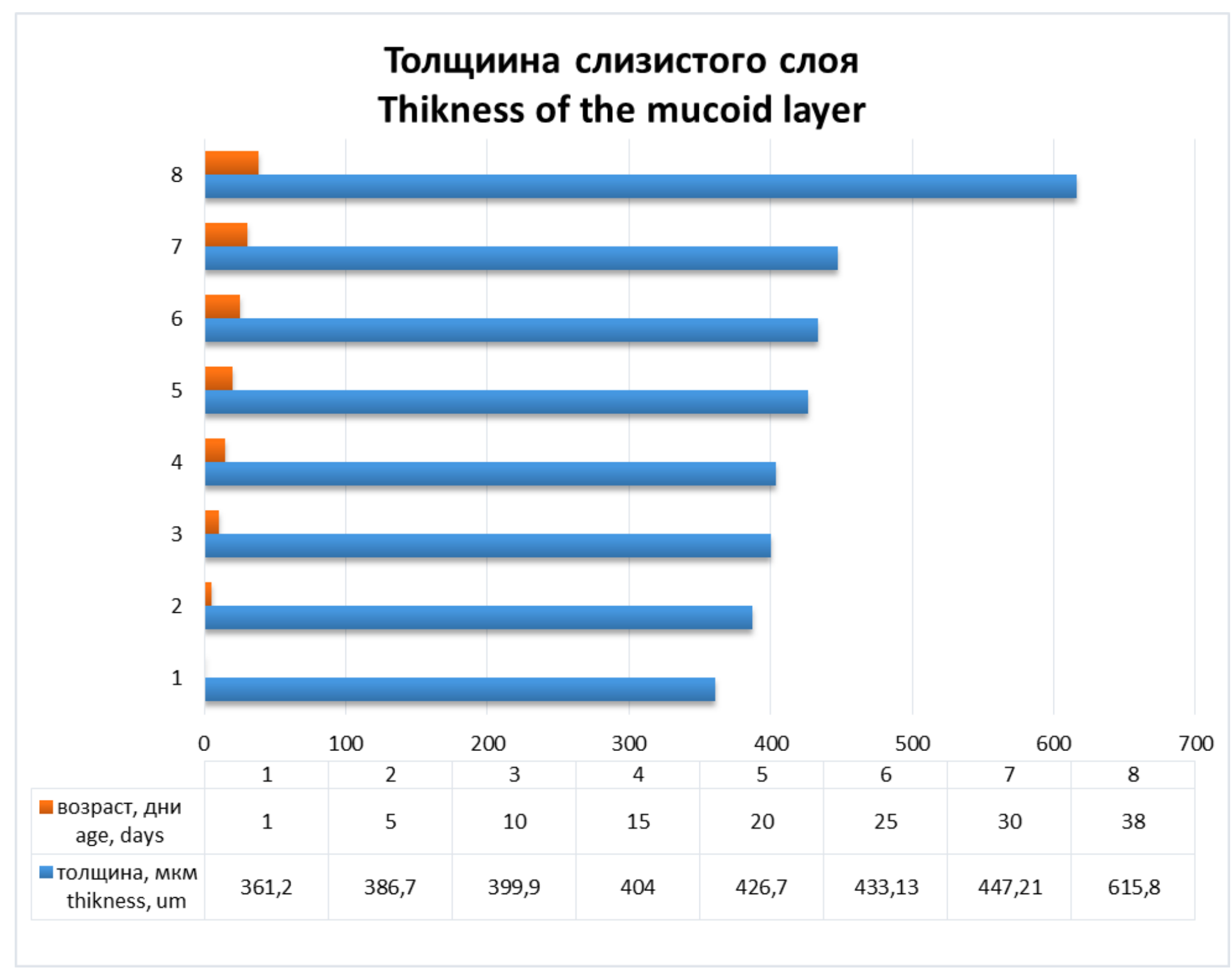

Рисунок 4 - Возрастная динамика толщины слизистого слоя железистого желудка, мкм Figure 4-Age-related dynamics of the thickness of the mucous layer of the glandular stomach, microns

Мышечная пластинка слизистой оболочки желудка образована одним слоем пучков гладких миоцитов.

В нашем опыте мышечная пластинка слизистой оболочки железистого отдела желудка увеличивалась в размерах постепенно. Так, у цыплят суточного возраста она составила 7,86 $\pm 0,09$ мкм, а к 10 суткам данный показатель увеличился лишь на 1,48 мкм, к 20-ти дням на 1,43 мкм, к 30-ти дням изучаемый показатель возрос на 1,37 мкм. Толщина мышечной пластинки у 38-дневных цыплят-бройлеров изменилась незначительно и составила $12,91 \pm 0,23$ мкм.

Подслизистая основа слизистой оболочки железистого отдела цыплят-бройлеров кросса Росс 308 представлена рыхлой соединительной тканью, которая содержит глубокие железы, аналогичные собственным (фундальным) железам желудка млекопитающих. Это сложные альвеолярные, вырабатывающие пепсиноген и соляную кислоту, крупные железы, заметные невооруженным глазом. Они так плотно уложены, что межжелезистой соединительной ткани почти не видно и, слизистая оболочка принимает вид губки. 
Доли глубоких желез со всех сторон окружены соединительной тканью, содержащей коллагеновые и эластические волокна, а также пучками мышечных клеток, заходящих сюда из мышечной пластинки слизистой оболочки. Анализ гистологических препаратов показал, что развитие подслизистой основы имело волнообразное течение. На 6 и 7, 13 и 14, 27 и 28 сутки наблюдались периоды угасания роста. Аналогичная закономерность прослеживалась при изучении толщины слизистой оболочки железистого желудка.

Так, у суточных цыплят-бройлеров толщина подслизистой основы железистого отдела желудка составила 1769,88 8 ,56 мкм, на 5 сутки увеличилась в 1,55 раза. На 10 сутки толщина подслизистой основы желудка у цыплят-бройлеров кросса Росс 308 увеличилась на 93,72 мкм, на 20 день - на 147,61 мкм, на 30 сутки - на 721,25 мкм по сравнению с предыдущим возрастом, и на 38 сутки изучаемый показатель увеличился еще на 485,0 мкм, что составило 4190,89 мкм.

Проведенные гистологические исследования железистого желудка выявили асинхронное развитие его слоёв. В процессе роста слизистого и подслизистого слоев наблюдались периоды покоя в 6-7, 13-14 и 27-28 дней. Полученные нами данные не имеют аналогов в мировой практике исследований.

Заключение. Эффективность выращивания конкретного кросса птицы зависит от многих факторов, в том числе от особенностей роста и развития молодняка, скорости созревания птицы, ее сохранности и делового выхода. Изучение в динамике (1-40 суток) морфологии железистого желудка цыплят на уровне микроструктуры позволило установить, что в гистологической структуре железистого отдела желудка цыплят-бройлеров кросса Росс-308 отмечалось равномерное увеличение толщины мышечной пластинки с 1 по 38 сутки в 1,71 раза. В процессе развития слизистой и подслизистой основы железистого желудка установлены периоды покоя в росте клеток, которые приходятся на возраст 6-7, 13-14 и 27-28 дней. Полученные результаты исследований позволяют в более ранние сроки, в возрасте 7 дней, проводить смену престартерного рациона кормления на стартерный, что повышает экономическую эффективность производства мяса бройлеров.

Конфликт интересов. Авторы заявляют об отсутствии конфликта интересов.

Conflict of interest. The authors declare no conflict of interest.

\section{Библиографический список}

1. Азарнова, Т.О. Некоторые аспекты трансовариального питания эмбрионов кур и стимуляции развития их пищеварительного тракта / Т.О. Азарнова, И.С. Ярцева, С.Ю. Зайцев [и др.] // Международный вестник ветеринарии. - 2012. - № 4. - С. 5457.

2. Анацкая, О.В. Структура клеточной популяции гепатоцитов птенцовых и выводковых птиц с различной массой тела / О.В. Анацкая, А.Е. Виноградова, Н.Н. Смирнова // Цитология. - 2000. - Т. 42. - № 3. - С. 257.

3. Бодрова, Л.Ф. Гистоморфологическая характеристика мускульного желудка кур при содержании их на рационах с разным количеством отрубей / Л.Ф. Бодрова // Аграрный вестник Урала. - 2008. - № 8. - С. 64-66. 
4. Бодрова, Л.Ф. Гистоструктура стенки выводных протоков поджелудочной железы кур / Л.Ф. Бодрова, Г.А. Хонин, В.А. Шестаков // Ветеринарный врач. - 2009. - № 2. - C. 70-72.

5. Ваххаб, С.А. Закономерности морфогенеза железистого желудка цыплят кроссов ROSS-308 и ХайсексБраун в постинкубационном онтогенезе / С.А. Ваххаб, О.С. Бушукина // XIV Огарёвские чтения: мат. науч. конф. - Саранск, 2017. - С. 48-55.

6. Глаголев, П.А. Анатомия сельскохозяйственных животных с основами гистологии и эмбриологии / П.А. Глаголев, В.И. Ипполитова, под ред. И.А. Спирюкова, В.Ф. Вракина. - 4-е изд. перер. и доп. М.: Колосс, 1997. - С. 319-322.

7. Гришина, Д.Ю. Возрастная морфометрия печени кур в постнатальном периоде / Д.Ю. Гришина // Известия Самарской государственной сельскохозяйственной академии. - 2011. - № 1. - С. 55-58.

8. Дышлюк, Н.В. Развитие стенки промежуточной зоны железистой части желудка кур в пренатальном периоде онтогенеза / Н.В. Дышлюк // Сельскохозяйственные науки и агропромышленный комплекс на рубеже веков. - 2014. - № 5. - С. 217-222.

9. Зайцева, Е. Возрастная гистология железистого желудка кур / Е. Зайцева, Е. Родина // Птицеводство. - 2006. - № 9. - С. 34.

10. Матвеев, О.А. Гистоархитектоника железистого и мышечного желудка цыплятбройлеров кросса ROSS-308 в постинкубационном периоде онтогенеза / O.А. Матвеев, М.М. Жамбулов, И.В. Чекуров, П.П. Макаров // Известия Оренбургского государственного аграрного университета. - 2018. - № 4. - С. 237-241.

11. Муллакаев, А.О. Морфологическая характеристика органов пищеварительной системы у бройлеров в условиях применения естественных минералов / А.О. Муллакаев, А.А. Шуканов, О.Т. Муллакаев // Ветеринарный врач. - 2013. - № 1. - С. 64-66.

12. Тайгузин, Р.Ш. Особенности морфологии железистого желудка цыплят-бройлеров при гипотрофии и коррекции пробиотиками Ветом 1.1 и Лактобифадол / Р.Ш. Тайгузин, К.Д. Джамбулатова // Известия Оренбургского государственного аграрного университета. - 2015. - № 6 (56). - С. 113-116.

13. Тайгузин, Р.Ш. Особенности гистологии железистого отдела желудка цыплятбройлеров кросса СОВВ-500 / Р.Ш. Тайгузин, И.Р. Азнабаев // Известия Оренбургского государственного аграрного университета. - 2017. - № 2 (64). - С. 117-119.

14. Черепанова, Н.Г. Гистология кишечной стенки цыплят-бройлеров при использовании различных биодобавок / Н.Г. Черепанова, Е.А. Просекова, Е.В. Панина, В.П. Панов, А.Э. Семак, М.В. Сидорова, А.А. Концевова // Известия Тимирязевской сельскохозяйственной академии. - 2019. - № 1. - С. 98-112.

\section{Reference}

1. Azarnova, T.O. Nekotorye aspekty transovarial'nogo pitaniya embrionov kur i stimulyacii razvitiya ih pishchevaritel'nogo trakta / T.O. Azarnova, I.S. Yarceva, S.Yu. Zajcev [i dr.] // Mezhdunarodnyj vestnik veterinarii. - 2012. - № 4. - S. 54-57.

2. Anackaya, O.V. Struktura kletochnoj populyacii gepatocitov ptencovyh i vyvodkovyh ptic s razlichnoj massoj tela / O.V. Anackaya, A.E. Vinogradova, N.N. Smirnova // Citologiya. - 2000. - T. 42. - № 3. - S. 257.

3. Bodrova, L.F. Gistomorfologicheskaya harakteristika muskul'nogo zheludka kur pri soderzhanii ih na racionah s raznym kolichestvom otrubej / L.F. Bodrova // Agrarnyj vestnik Urala. - 2008. - № 8. - S. 64-66. 
4. Bodrova, L.F. Gistostruktura stenki vyvodnyh protokov podzheludochnoj zhelezy kur / L.F. Bodrova, G.A. Honin, V.A. Shestakov // Veterinarnyj vrach. - 2009. - № 2. - S. 7072.

5. Vahkhab, S.A. Zakonomernosti morfogeneza zhelezistogo zheludka cyplyat krossov ROSS-308 i HajseksBraun v postinkubacionnom ontogeneze / S.A. Vahkhab, O.S. Bushukina // XIV Ogaryovskie chteniya: mat. nauch. konf. - Saransk, 2017. - S. 4855.

6. Glagolev, P.A. Anatomiya sel'skohozyajstvennyh zhivotnyh s osnovami gistologii i embriologii / P.A. Glagolev, V.I. Ippolitova, pod red. I.A. Spiryukova, V.F. Vrakina. - 4-e izd. perer. i dop. M.: Koloss, 1997. - S. 319-322.

7. Grishina, D.Yu. Vozrastnaya morfometriya pecheni kur v postnatal'nom periode / D.Yu. Grishina // Izvestiya Samarskoj gosudarstvennoj sel'skohozyajstvennoj akademii. 2011. - № 1. - S. 55-58.

8. Dyshlyuk, N.V. Razvitie stenki promezhutochnoj zony zhelezistoj chasti zheludka kur v prenatal'nom periode ontogeneza / N.V. Dyshlyuk // Sel'skohozyajstvennye nauki i agropromyshlennyj kompleks na rubezhe vekov. - 2014. - № 5. - S. 217-222.

9. Zajceva, E. Vozrastnaya gistologiya zhelezistogo zheludka kur / E. Zajceva, E. Rodina // Pticevodstvo. - 2006. - № 9. - S. 34.

10. Matveev, O.A. Gistoarhitektonika zhelezistogo i myshechnogo zheludka cyplyat-brojlerov krossa ROSS-308 v postinkubacionnom periode ontogeneza / O.A. Matveev, M.M. Zhambulov, I.V. Chekurov, P.P. Makarov // Izvestiya Orenburgskogo gosudarstvennogo agrarnogo universiteta. - 2018. - № 4. - S. 237-241.

11. Mullakaev, A.O. Morfologicheskaya harakteristika organov pishchevaritel'noj sistemy u brojlerov $\mathrm{v}$ usloviyah primeneniya estestvennyh mineralov / A.O. Mullakaev, A.A. Shukanov, O.T. Mullakaev // Veterinarnyj vrach. - 2013. - № 1. - S. 64-66.

12. Tajguzin, R.Sh. Osobennosti morfologii zhelezistogo zheludka cyplyat-brojlerov pri gipotrofii i korrekcii probiotikami Vetom 1.1 i Laktobifadol / R.Sh. Tajguzin, K.D. Dzhambulatova // Izvestiya Orenburgskogo gosudarstvennogo agrarnogo universiteta. - 2015. - № 6 (56). - S. 113-116.

13. Tajguzin, R.Sh. Osobennosti gistologii zhelezistogo otdela zheludka cyplyat-brojlerov krossa COBB-500 / R.Sh. Tajguzin, I.R. Aznabaev // Izvestiya Orenburgskogo gosudarstvennogo agrarnogo universiteta. - 2017. - № 2 (64). - S. 117-119.

14. Cherepanova, N.G. Gistologiya kishechnoj stenki cyplyat-brojlerov pri ispol'zovanii razlichnyh biodobavok / N.G. Cherepanova, E.A. Prosekova, E.V. Panina, V.P. Panov, A.E. Semak, M.V. Sidorova, A.A. Koncevova // Izvestiya Timiryazevskoj sel'skohozyajstvennoj akademii. - 2019. - № 1. - S. 98-112.

E-mail: niimmp@mail.ru

Получено / Received: 04-02-2020

Принято после исправлений / Accepted after corrections: 18-02-2020 